Тулъчинский Г. Л. Аостоевский: антиутопии Xх века и предупреждение о настоящем // Философия. Журнал Высшей школы экономики. - 2021. - Т. 5, № 3. - С. 56-72.

\title{
Григорий Тульчинский*
}

\section{АОСТОЕВСКИЙ: АНТИУТОПИИ ХХ ВЕКА И ПРЕАУПРЕЖАЕНИЕ О НАСТОЯЩЕМ ${ }^{* *}$}

Получено: 12.06.2021. Рецензировано: 22.08.2021. Принято: 26.08.2021.

Аннотация: При всем различии антиутопий Е. Замятина, А. Платонова, О. Хаксли, А. Оруэлла, Р. Брэдбери, к которым в наше время обращаются как к предостережениям относительно тенденций развития цивилизации, общность выраженных в них мыслей прослеживается в творчестве Ф. М. Аостоевского. Речь идет о критике Аостоевским идейных корней и возможных последствий реализации программы переустройства общества, ориентированного исключительно на преобразование социальной среды бытия. В этом плане вызывает особый интерес притча о Великом инквизиторе в романе «Братья Карамазовы», которая предстает концентрацией ключевых идей упомянутых антиутопий. Главный урок парадигмальной антиутопии притчи Аостоевского-опасность принудительного добра, стремления к реализации его «сверху», преобразования властной волей материальных условий универсальной для всех безопасности и сытости. В этой логике уловлен болевой нерв рационализма Нового времени в его стремлении к изменению мира. Исторический опыт подтверждает предупреждение Аостоевского о том, что реализация такой программы требует перманентного насилия над природой, обществом, человеком. Искушению власти собственной властью может быть противопоставлена программа формирования гармонии социума без использования насилия, когда справедливость творится во имя сохранения этой гармонии, когда зло свидетельствует об отступлении от этого пути, о необходимости понять, что и как необходимо сделать, чтобы вернуться на путь гармонии и добра. В этой ситуации нравственной оценке подлежкат не цели, а средства, которые используются для достижения целей.

Ключевые слова: антиутопии, благоденствие, власть, Аостоевский, насилие, современность, социализм.

DOI: $10.17323 / 2587-8719-2021-3-56-72$.

\section{ВВЕДЕНИЕ. ПОСТАНОВКА ЗАДАЧИ}

Глубокое осмысление проблем человеческого бытия, представленное $\Phi$. М. Достоевским, не просто сохраняет свою актуальность для социальной философии, философии культуры и личности, философской

*Тульчинский Григорий Львович, д. филос. н., профессор, НИУ «Высшая школа экономики» (Санкт-Петербург), gtul@mail.ru, ORCID: oooo-0002-5820-7333.

** (C) Тульчинский, Г. Л. (C) Философия. Журнал Высшей школы экономики.

Благодарности: исследование выполнено при поддержке гранта РНФ № 20-68-46013 «Философско-антропологический анализ советского бытия. Предпосылки, динамика, влияние на современность». 
антропологии. Оно дает возможность понимать источники вызовов, с которыми сталкивается современная цивилизация, оценивать последствия ответов на эти вызовы.

Примером реализации такой возможности является обращение к Достоевскому в осмыслении антиутопий хх столетия: как показывает цивилизационное развитие в XхI, тенденции динамики социума, отмеченные в этих антиутопиях, продолжаются и даже реализуются в наши дни, обретая форматы, поддерживаемые достижениями науки и техники. Однако обращение к содержанию этих антиутопий показывает, что при всем их различии концептуально ядро этого содержания в концентрированной форме выражено Достоевским в его критике социалистических идей, проходящей сквозной темой в ряде его романов («Бесы», «Братья Карамазовы»), повестей («Сон смешного человека», «Записки из подполья»), в «Дневнике писателя», в ряде писем. Достоевский обосновывает и развивает эту критику в христологическом контексте православия, однако ее глубина и сила обобщений выводит в широкий горизонт осмысления источников, целей, реализации программ переустройства общества, человека, мира и попыток их осуществления на основе обещания материального благоденствия под заботливым попечением власти, реализующей условия такого благоденствия. В горизонте осмысления Достоевского оказываются не только пророчества антиутопий, реалии советского эксперимента и его краха, но и - что немаловажно - реалии социального бытия, открывающиеся только в наше время. Речь идет о радикальных трансформациях практически всех сфер социальной жизни (экономики, политики, образования, науки, личной жизни), обеспеченных современными коммуникативными технологиями в цифровом формате.

Ограниченные возможности статьи вынуждают сузить круг привлекаемых текстов. Решение этой задачи существенно облегчает наличие в творческом наследии Достоевского замечательного фрагмента, в котором ключевые для анализа идеи выражены наиболее полно и ярко. Имеется в виду небольшой фрагмент пятой главы пятой книги последнего романа Достоевского «Братья Карамазовы» - «поэмка», рассказанная Иваном Карамазовым младшему брату Алеше при их встрече в трактире. Этот фрагмент сразу вызвал бурную дискуссию, в ходе которой получил с легкой руки В. В. Розанова название «Легенда о Великом инквизиторе» (далее-ЛВИ). Сам текст ЛВИ, его анализ и толкования в работах К. Н. Леонтьева, В. С. Соловьева, В. В. Розанова, С. Н. Булгакова, Н. А. Бердяева, С. Л. Франка, удачно собранные 
Ю. И. Селиверстовым в одной книге (О великом инквизиторе, 1992), дают довольно полное представление о содержании и значении как самой ЛВИ, так и ее обсуждения и интерпретаций. Как мы постараемся показать в данной статье, эта притча является гениальным сосредоточением идей, представленных авторами антиутопий, и обоснованно может считаться содержательной парадигмой предупреждений, представленных в этих антиутопиях, важных для философского осмысления современных социальных трансформаций.

Логика дальнейшего рассмотрения предполагает, во-первых, определение круга анализируемых антиутопий и выявление в их содержании некоего инварианта ключевых идей. Во-вторых, важно сопоставить эти идеи, предупреждавшие о неоднозначных тенденциях, осознанных к середине прошлого столетия с современной реальностью. Тем самым, в-третьих, открывается обратная перспектива к ЛВИ, в которой проявляется не только неоднозначность парадигмы доминирующей до сих пор тенденции развития человеческого общества, но и горизонт альтернатив.

АНТИУТОПИИ: ЦЕННОСТНО-НОРМАТИВНЫЙ ИНВАРИАНТ

Антиутопия (дистопия, какотопия) - суть оценочное, прежде всего этическое отрицание утопического идеала, критическая рефлексия утопии, выводящая за утопический горизонт-к осмыслению ценностей политической и философской антропологии (Хаустов, 2019: 144-147). Если утопия описывает желаемое будущее, соответствующее неким идеалам, возможным технологиям и трендам развития, то антиутопия предупреждает о нежелательных последствиях реализации некоторых идеалов и наметившихся тенденций развития.

Круг антиутопий прошлого столетия довольно широк. Наиболее известны романы Е. Замятина «Мы» (написан в 1920 г., впервые опубликован в английском переводе в 1925 г.), О. Хаксли «О дивный новый мир» (1932 г.), Д. Оруэлла «Тысяча девятьсот восемьдесят четвертый» (1948 г.), после Второй мировой войны их дополнила повесть Р. Брэдбери «451 градус по Фаренгейту» (1953г.).

Содержание антиутопий хорошо известно всей читающей публике. Сразу после их публикации оно привлекло внимание, вызвало длящееся до наших дней активное обсуждение. Стоит отметить, что Оруэлл хорошо знал оба других романа. С Хаксли они дружили. А в период работы над своим текстом в 1946 году он написал рецензию на «Мы», в которой отметил, что роман Хаксли, видимо, отчасти обязан своим появлением этой книге: в обоих произведениях действие перенесено 
в будущее на 600 лет, в них фактически изображен один и тот же тип общества с различной расстановкой акцентов. У Замятина на первом плане - политический подтекст происходящего в романе, тогда как у Хаксли-использование биологических и психологических технологий. Широко распространено мнение, что Замятин и Оруэлл писали сатиру на советский строй. Действительно, некоторые детали, а главное-ряд принципиальных аргументов, объясняющих общество, описываемое в романах, шокирующе совпадают с советскими реалиями и аргументами пропаганды. Но антиутопия Хаксли описывает общество, существенно иное - в котором люди, живущие в безопасности и достатке, получают все, чего хотят, и не способны хотеть то, чего получить не могут, что делает мир, описываемый Хаксли, близким обществу массового потребления. Это наводит на поиск их более общего идейного бэкграунда.

Первое приближение в таком поиске дает возможность предположить, что Хаксли и Оруэлл отталкивались от идей фабианского социализма, проповедующего построение справедливого общества на основе постепенного все большего вмешательства государства в экономику и социальные процессы в целом. Общество было названо в честь древнеримского полководца Фабия Максима Кунктатора (Медлительного), практиковавшего стратегию не решительных битв, а истощения противника, приводящей к победе. Членами Фабианского общества были Б. Рассел, Г. Уэллс, Б. Шоу, Д. М. Кейнс, крупные политики и журналисты. Фабианцы учредили влиятельную Лондонскую школу экономики, стояли у истоков создания лейбористской партии, в основу устава которой положен ряд документов общества. Круг фабианских трактатов, написанных с 1884 по 2000 годы крупными учеными, политическими и религиозными деятелями, писателями и публицистами, насчитывает 597 книг (Fabian Society..., 2000).

Хаксли и Оруэлл были активными членами Фабианского общества, в которое Оруэлла ввел именно Хаксли, преподававший ему в Итоне французский язык. В то время в обществе доминировала активно продвигавшаяся Уэллсом идея «открытого заговора» (open conspiracy) воплощения социалистических идей не с помощью захвата власти и диктатуры пролетариата, а постепенно, посредством влияния через академическую среду и медиа на правительство с последующим доминированием такого правительства (Wells, 1928).

Этот круг идей восходит к рационалистическому культу науки и сайентизму, включая Жюль Верна и Г. Уэллса. Практически параллельно развивались восходящие к романтизму концепции в духе эстетической 
утопии Р. Вагнера воплощения художником в творении универсального артефакта (Gesamtkunstwerk) сопричастности всемирной воле. Насколько утопии разума и воли оказывали взаимное влияние-заслуживает отдельного рассмотрения, но за рубежом давно стало предметом осмысления то внимание, которое уделяли социалистическим идеям теоретики и практики фашизма, опасность современного сближения двух идеологий (Gross, 1980; Goldberg, 2009). Хотя Уэллс признавал, что научно-технический прогресс может привести к человеческим страданиям, и предвидел огромную разрушительную силу атомной бомбы, создание технологий, разрушающих конфиденциальность, а Оруэлл признавал важность науки и новых технологий в противостоянии фашистской Германии, их взгляды на роль науки и ученых радикально разошлись. Уэллс главным условием рационализации политического устройства мира видел именно научный склад ума, полагая, что будущее в руках ученых. Оруэлл, приводя пример немецких ученых, пошедших за Гитлером, отвергал такую стратегию (Wells, Hitler and the World State, 1941) и вышел из общества. Он был категорически против такого будущего, считая, что именно чисто научное мышление открывает возможности тоталитаризму (H. G. Wells vs. George Orwell, 2017). Так что название его антиутопии содержит прямую аллюзию на столетие создания Фабианского общества (1884 год). Показательно и то, что Замятин привез замысел своей антиутопии после работы и интенсивного общения с научно-технической элитой в той же Великобритании.

Влиятельные сторонники фабианского социализма и активные фабианцы проявляли искренний интерес к советскому опыту, лоббировали оказание помощи сталинскому режиму во время индустриализации, в военное время. Так, Герберт Уэллс после первой поездки 1920 года в советскую Россию и обстоятельной беседы с В. И. Лениным написал знаменитое эссе «Россия во мгле», весьма доброжелательное по отношению к «кремлевскому мечтателю». Во второй поездке 1933 года Уэллс был принят Сталиным. Бернард Шоу также ездил в СССР и видел в нем надежду на спасение человечества от краха, встречался в 1931 году со Сталиным, о котором отзывался не только как об очень приятном человеке и настоящем руководителе рабочего класса, но и как об интеллектуальном гиганте, по сравнению с которым западные деятели выглядят пигмеями. Он и в дальнейшем поддерживал сталинизм, оправдывал массовые репрессии, кампанию против генетиков (Yde, 2013).

Активным сторонником фабианства был и бывший троцкист Д. Бёрнхем, предложивший термин «революция менеджеров», выпустивший 
под таким названием в 1941 году книгу (Burnham, 1941), которая сразу после выхода наделала шума в США и Европе. В ней Д. Бёрнхем предрекал новый тип централизованного общества. Правящим классом в этом обществе будут те, кто реально контролирует средства производства: руководители компаний, бюрократы-администраторы, военные. Всех их он объединял в одну категорию «менеджеров». Эти люди устранят традиционных капиталистов, окончательно сокрушат рабочий класс и сосредоточат в своих руках экономические ресурсы и власть. Место многочисленных национальных государств займут некие большие сверхгосударства, сложившиеся вокруг индустриальных и экономических центров Европы, Азии и Америки. Их политические системы будут иерархичными - с менеджериальной элитой наверху. В 1940 году он писал, что «менеджеризм» достиг наивысшего развития в СССР, но почти так же развит в гитлеровской Германии и уже заявил о себе в Соединенных Штатах в виде рузвельтовского «нового курса», который Д. Бёрнхем характеризовал как «примитивный менеджеризм». Показательно, что еще $\Phi$. Энгельс в конце жизни (он умер в 1895 году), комментируя распространение практики акционерных обществ, которая как раз и вела к появлению фигуры управляющего, оценивал это как еще один симптом кризиса традиционного капитализма.

В рецензии на очередную публикацию «Революции менеджеров» в 1946 году Д. Оруэлл отмечал, что круг этих идей лежит в русле предсказаний появления нового общества, которые восходят к утопиям Платона, Т. Мора, Т. Кампанеллы, Д. Бентама, а в хх веке близко к ним подошли Х. Беллок в «Рабском государстве» (1911), Джек Лондон в «Железной пяте» (1909). После Второй мировой войны за таким типом государства закрепился термин «тоталитарное», пришедший из итальянского опыта характеристики муссолиниевского корпоративного государства во главе с надпартийным лидером.

Позже фабианские по сути идеи получили респектабельное развитие у таких социологов, как П. Друкер, П. Сорокин, Д. Белл, Т. Парсонс, Р. Дарендорф, Д. Гэлбрейт, писавших о росте масштабов контроля управленческим аппаратом над различными проявлениями общественной и отчасти личной жизни... Эти идеи сохранили влияние и в наше время, особенно в университетской среде, в кругах художественной интеллигенции, а политически это выразилось в поддержке Б. Сандерса, электорат которого подхватил Д. Байден. 
Так что антиутопии хх столетия имеют хорошо обоснованный идейный бэкграунд, уходящий в глубокую традицию европейской общественной мысли, которая проявляется и в наши дни. Каков общий инвариант идей этих антиутопий?

Прежде всего, это научно-технический прогресс, который в отрыве от нравственного, духовного развития не только не способствует улучшению человеческой природы, но и грозит вытеснить человеческое в человеке. Это предупреждение, этот вызов из сферы литературы и философии в наши дни уже стал темой общественного дискурса и в публицистике, и в медиа, и даже в обыденном опыте. Порожденный достижениями и последствиями цифровизации и биотехнологий аларм, переходящий в хорроризацию, стал реалией нашего времени.

В зазеркалье антиутопий технологические достижения, использующие их институты, органы задуманы для защиты граждан, для заботы об их безопасности, но именно они становятся основным инструментом насилия над ними. В «451 градусе по Фаренгейту» Брэдбери описан близкий к современности мир, в котором живут массово осчастливленные в духе Хаксли потребители, разговаривающие только о вещах, телесериалах, брендах, а пожарные, задуманные для предупреждения и тушения пожаров, занимаются сжиганием книг и жилищ людей, хранящих книги.

Сам Брэдбери считал себя учеником Оруэлла (Брэдбери, Покидаева, 2020: 53), потому как весь его текст- одна сплошная метафора реализации репрессивного насилия, которого сторонится Хаксли. Тема насилия действительно наглядно представлена в романе Оруэлла как откровенная, демонстративная практика не только целенаправленно перемалывающая главного героя, но и нагнетаемая состоянием непрерывного военного внешнего противостояния, регулярными 10-минутками ненависти, неминуемыми для каждого члена социума. В «Мы» насилие тоже представлено, но фоново, как неизбежное следствие тотального контроля за возможными поведенческими отклонениями.

Это тоже хорошо знакомо людям в современной реальности: ценность безопасности оборачивается тотальной секьюритизацией- обеспечением не просто государственной внешней и внутренней безопасности, но и безопасности информационной, коммуникативной, медицинской, культурной, образовательной, научной, цифровой, климатической и т. д. Фактически декларируемая безопасность служит основанием тотальному контролю, следствием которого, в свою очередь, является угроза или реализация насилия. В результате складывается самодостаточная 
система хорроризации: страх утраты благополучного настоящего, рационально созданной искусственной среды, с одной стороны, и искусственно создаваемый и культивируемый хоррор - с другой.

Идеи счастья и страха тесно переплетаются и дополняют друг друга в любой утопии: от Платона и Гоббса до рассматриваемых антиутопических романов. Это сцепление характерно и для современности: постиндустриальное общество массового потребления реализовало великий проект гуманизма Просвещения с его лозунгами «Все для человека», «Все во имя человека!», «Человек есть мера всех вещей!». Это общество в состоянии удовлетворить и даже стимулировать любую потребность: оно утратило образ будущего и этого будущего страшится.

$\mathrm{K}$ счастью и страху непосредственно примыкает идея реализации справедливости - второй после безопасности базовой ценности социогенеза. Как только возникает некая общность, в ней появляются напряжения, связанные с признанием, влиянием, привлекательностью, доминированием - всем тем, что порождает зависть, ресентимент. Это обусловливает запрос жить по правилам, по-честному, справедливо. Характерно, что в антиутопиях речь идет о справедливости не только и даже не столько как о равенстве перед законом, но и как о справедливости распределительной-в зависимости от заслуг или других качеств членов общества, оцениваемых с точки зрения интересов общности.

Мир антиутопий - мир торжествующего унифицирующего коллективизма, выраженного в беспощадном равенстве не перед законом, а в равенстве, доводимом до одинаковости, если не тождественности. Об этом с большим пафосом поучает в «451 градусе по Фаренгейту» главного героя его начальник-брандмастер Битти, обосновывающий необходимость уничтожения книг тем, что начитанный человек опасен: рядом с ним другие могут почувствовать себя униженными.

Можно констатировать, что смысловая картина мира во всех антиутопиях хх столетия при всех их отличиях имеет общие компоненты, включающие:

$\diamond$ установку на формирование общества благоденствия и счастья всех его членов, понимаемого как удовлетворение жизненных потребностей и отсутствие страданий;

$\diamond$ реализацию этой установки за счет создания искусственной материальной среды, противостоящей естественной: основой такого противостояния являются рационалистические претензии на преобразование природы (включая человека) на основе познанных законов самой природы; 
$\diamond$ вырождение рациональности до оправдания насилия над природой, социумом и человеком во имя неких общих принципов, которым оборачивается реализация таких претензий;

$\diamond$ следствие: практика тотального контроля индивидуальных отклонений, вплоть до проявлений творчества, и перманентного насилия, заканчивая физическим уничтожением;

$\diamond$ результат: порядок в социуме поддерживается тотальным страхом - как тем, который внушается сверху хоррором насилия, так и тем, который испытывают сами верхи перед проявлениями свободы.

Таким образом, обращение к содержанию антиутопий позволяет сделать два важных промежуточных вывода. Во-первых, относительно объединяющей их идеи, что счастье и свобода оказываются несовместимыми. Такой вывод иногда трактуется как «формула» любой антиутопии как литературного жанра (Хаустов, 2019: 138). Будучи правоверным членом социума, герой обнаруживает в себе естественные стремления и способности, их несовместимость с существующим порядком; примыкает к сообществу таких же бунтарей против системы, что дает некоторую надежду, но завершается трагическим крахом. И, во-вторых, круг идей, от которого в буквальном смысле слова отталкивались авторы антиутопий, связан так или иначе с идеями построения общества на рационалистических принципах обезличенного универсального коллективизма, реализуемых практически неограниченной властью.

Как это соотносится с ЛВИ Достоевского, писавшего вроде бы не предупреждение о будущем, а притчу о якобы прошлом?

\section{ПАРАДИГМАЛЬНОСТЬ ДОСТОЕВСКОГО}

Практически все исследователи упоминавшихся антиутопий хх века отмечают их близость ЛВИ. Так, текст статьи, которую читает герой «Мы»,- непосредственно прямая цитата речи Великого Инквизитора из притчи Достоевского. Фигура и аргументация Великого Инквизитора использованы Оруэллом в образе О’Брайена.

Содержание ЛВИ хорошо известно. Суть описанной в ней ситуации в явлении Христа в XVI веке в Севилье, в самый разгар инквизиционных гонений на еретиков. По милости, проявляемой к гонимым, Сына Божьего распознают, но его прославление останавливает Великий Инквизитор, приказывающий заключить Христа в темницу, куда он сам приходит ночью к узнику. Главное содержание притчи - это монолог Великого Инквизитора, с которым тот обращается к Христу, убеждая 
его покинуть мир, иначе наутро он будет публично казнен как опаснейший еретик. За все время этой сцены Христос не произносит ни слова, но уходит, поцеловав на прощание Великого Инквизитора.

Сам Достоевский публично читал этот фрагмент на литературном благотворительном мероприятии 30 декабря 1879 года в Санкт-Петербурге и в своем вступительном слове отмечал, что в этом тексте «под видом социальной любви к человечеству является уже не замаскированное презрение к нему» (О великом инквизиторе, 1992: 13).

В аргументации Великого Инквизитора фактически представлена развернутая антропология власти. Она сводится к тому, что второе пришествие Спасителя разрушит социальный мир, построенный такими продолжателями его учения, как сам Великий инквизитор. Смысл этого мира в том, что

люди уверены более чем когда-нибудь, что свободны вполне, а между тем сами же они принесли нам свободу свою и покорно положили ее к ногам нашим (там же: 33).

И это сделало людей счастливыми, тогда как стремление к свободе делает человека бунтовщиком - человеком изначально несчастным.

Великий Инквизитор полагает, что, отвергнув три искушения (накормить людей, завоевать веру с помощью чуда и стать владыкой всего мира), Христос совершил великую ошибку, наконец-то исправленную его последователями. Люди хотят не свободы, а чтобы их накормили, ради хлеба они способны отвергнуть любую мораль и мудрость, тогда как свобода только приносит дополнительные страдания. Что касается оснований веры, то, согласно Великому Инквизитору, человек ищет не столько Бога, сколько чудес: отвергнув чудо, он тотчас отвергнет и Бога. А главная ошибка Спасителя, по мнению Великого Инквизитора, касалась власти. И такие, как он, исправили «ошибку», взяв власть,

основав ее на чуде, тайне и авторитете, что сделало людей счастливыми, избавило их от страшного и мучительного дара свободы, что их повели, как стадо,

чему они только обрадовались (там же: $3^{-} 3^{2}$ ).

О, мы убедим их,... что они слабосильны, что они только жалкие дети, но что детское счастье слаще всякого. Они станут робки и станут смотреть на нас и прижиматься к нам в страхе, как птенцы к наседке (там же: 35 ).

Такой страх утраты благополучия и ответственности за возможность такой утраты обеспечивает сплочение социума вокруг носителей власти. 
Аргументация Великого Инквизитора - это антропология власти как избавления от свободы и ответственности, основанном на обещании благоденствия и счастья. Если «Бесах» концепция счастья через порабощение, предложенная Шигалевым, основана просто на «математическом» разделении человечества на 1 / 10 властителей, которым дозволено все и которые получают безграничную власть над остальными 9 / 10, то в ЛВИ эта концепция основана на человеческой природе.

Буквальным примером такой программы для Достоевского был социализм, имеющий целью прежде всего преобразование экономических и других материальных сторон жизни, что, как показал Достоевский еще во «Сне смешного человека», не меняет нравственную природу. В этом с Достоевским согласился бы персонаж антиутопии Хаксли Мустафа Монд, запрещающий публикацию научного трактата, который может поставить под сомнение веру в счастье как высшее благо тем, что назначение жизни не в поддержании благоденствия, а в углублении и облагораживании сознания, обогащении знания.

Достоевский видел альтернативу этому историческому пути, наметившемуся в его время, в реализации нравственного идеала, представленного православными праведниками. При всей привлекательности такой путь сталкивается с проблемой расширения опыта в конечном счете на все человечество. Начинать решение этой проблемы, по Достоевскому, надо не «сверху», не «от общего», не с переустройства жизни социума, а «снизу», с работы ума и души каждого его члена; не когда человек не может творить зла, а когда он не хочет его творить.

Подход Достоевского иногда упрекают в «обращении мира в церковь и вытеснении государства» (Хархордин, 2011: 92). Однако Достоевский отвергает именно цезарепапизм на примере католичества, в котором он видел вытеснение церковью государства и слияние с ним. В ЛВИ продемонстрировано не подчинение государства церкви. Наоборот, речь идет о поглощении государством церкви, даже если власть рядится в церковные ризы и говорит о духовности, она все равно просто заменяет всякую этику своим насилием. При развитом гражданском обществе церковь, будучи его частью, может играть роль защитника индивида от покушения государства на его свободы. Но при отсутствии такой институциональной среды реализуется ситуация, представленная Достоевским. И убедительным примером этого является советский опыт, где

государство без Бога превратилось в церковь без Бога и с бесконечными претензиями на человеческую совесть... и всякий противник, даже мни- 
мый, должен покаяться в грехе прежде, чем его расстреляют (Синявский, 2002: 153).

А место божественной потусторонней трансцендентности занимает «светлое будущее», идеал которого оправдывает насилие как средство приближения этого будущего (Люббе, Куренной, 2016: 145), обесценивая жизнь целых поколений живущих.

Более того, запустив маховик насилия, такая система не может остановиться. Так, Сталин оправдывал новые и новые волны властного террора обострением классовой борьбы по мере строительства бесклассового коммунистического общества. А чрезвычайное положение, введенное в 1933 году после поджога Рейхстага, продолжалось до самой капитуляции Германии в 1945 году.

Показательно, что в наши дни с большим пиететом переводят и цитируют «теологического политолога» К. Шмитта, согласно которому сущностью политического является способность к жесткому, смертельному противостоянию Врагу (Шмитт, Кильдюшов, 2010). Эту способность обеспечивает власть, с помощью чрезвычайного положения отменяющая все правила и законы, что позиционирует ее как институциональный источник правил жизни и смерти. Характерно, что Шмитт фактически воспроизводит аргументацию Великого инквизитора: «Чрезвычайное положение имеет для юриспруденции значение, аналогичное значению чуда для теологии» (Шмитт, 2000: 57). Если чудо есть нарушение законов природы путем некоего непосредственного волевого вмешательства, то общественный порядок творится непосредственным вмешательством суверена. Тем самым светская власть сакрализуется, наделяется возможностью безграничного волеизъявления, включая неограниченное насилие.

С позиций «теологической политики» основания политического насилия возвышаются до уровня мессианизма - удержания порядка до второго пришествия Спасителя и последнего Страшного суда, вплоть до отмены реального второго пришествия, что и делает Великий инквизитор. Эта миссия удержания оправдывает стремление власти, конечной по своей сути, к бесконечному самопродолжению, что опять же оставляет систему в контуре перманентного насилия. И не случайно тот же Шмитт оправдывал «ночь длинных ножей» 30 июня 1934 года. А немного спустя этот юрист высшей квалификации заявил, что «фюрер создает право своей силой вождя» (Шмитт, Кильдюшов, 2010: 264), он определяет всё, не определяясь ничем и никем. Но это и есть триединство 
чуда, тайны и власти Великого Инквизитора: чудо и тайна власти, или власть как чудо и тайна, делающие властителя «смертным Богом».

Достоевский вовсе не был «теологическим политологом» в смысле К. Шмитта. Как подчеркивал К. Леонтьев, в ЛВИ представлен путь не любви и гуманности, а страха, горя и страдания (О великом инквизиторе, 1992: 52), превращающий обещанный социализмом Хрустальный дворец в его антипод - Курятник, Муравейник, - метафоры, часто звучащие у Достоевского. Такое превращение Великий инквизитор связывает с самой природой человека и человечества, стремлением к всемирности соединения, которое неизменно воплощалось в необходимость всеобщего преклонения, поскольку

самая природа человека уже извращена. И нет средства..., нет возможности другим способом устроить, сберечь и пожалеть племя извращенных существ, как приняв это самое извращение в основу;-собрать их рассыпавшееся стадо извращенной мыслью, ложь которой ответила бы лжи их природы (там же).

Как писал В.В. Розанов:

Большего отчаяния, чем какое залегло в эту странную и очень трудно опровержимую идею, никогда не было. Можно сказать, что это-самая грустная мысль, когда-либо проходившая через человеческое сознание,... самая тяжелая в целой всемирной литературе (там же: 156).

Главный урок парадигмальной антиутопии ЛВИ- опасность принудительного добра, стремления к реализации его «сверху», властной волей преобразования материальных условий универсальной для всех безопасности и сытости. В этой логике Великого инквизитора уловлен болевой нерв рационализма Нового времени в его стремлении к преобразованию мира. Иван Карамазов совпадает с гетевским Фаустом, но он делает следующий напрашивающийся шаг к оценке используемых средств такого преобразования, претендующего на всеобность, что оказывается невозможно без принудительной властной воли, без насилия. Суть этой модели самозванной справедливости замечательно выразил Бармалей в прекрасном фильме Р. Быкова «Айболит-66»: «Я вас всех запросто сделаю счастливыми! А кто не захочет-в бараний рог сверну, в порошок сотру и брошу акулам!»

Согласно тому же Гете, «общие понятия при большом самомнении могут привести к большой беде». А механизмом запуска «беды» оказывается «искушение власти властью». В ЛВИ представлено торжество самодостаточности власти как таковой и самой по себе, бесконтрольной и не подотчетной обществу, отчаянно стремящейся сохранить себя вечно. 
Однако силу власти обеспечивает не насилие, а ее легитимность, признание ее членами общества как справедливой. Как реальная история есть равнодействующая воль, так и реальная власть реализуется в балансе интересов социальных сил общества. Если власть прибегает к насилию, это признак ее слабости, несостоятельности к выстраиванию необходимой гармонии (Арендт, Дашевский, 2014; Кожев, Руткевич, 2006). А созданная на страхе и насилии власть будет вынуждена постоянно к ним прибегать, истощая и силы общества, и свои собственные. Реально это редукция политической антропологии власти к ее дезантропологии. Это было убедительно продемонстрировано фактической институционализацией пыток, лагерной практикой, доведенной до индустрии насилия и уничтожения.

В данной работе не время и не место углубляться в эту тематику. Достаточно будет сослаться на убедительно описанную Оруэллом феноменологию расчеловечивания болью и пыткой, которые редуцируют человека до его предельной, даже не «голой», а «нутряной» телесности.

Если у Достоевского на руках были преимущественно христологические аргументы оценки и осуждения, то хх столетие (чем дальше, тем больше) проясняло и проявляло, что эта антропология власти чревата отказом от собственно антропо-логии. В антиутопиях Великого инквизитора и Шигалева продемонстрирована опасность дезантропологии власти в программе современного ему социализма. Эти критика и предупреждение оказались применимыми не только к практике любого тоталитарного общественного обустройства, но и к инфантилизму общества массового потребления, зависимости от нажатия правильных опций, дающих доступ к «кормящей руке» обезличенных алгоритмов. Опасность такого развития событий Достоевским была предугадана точно. Он оказался прав в своей самооценке: он действительно являлся большим либералом, чем современные ему (и не только) либералы. Либерализм - не столько права человека, сколько его ответственность.

Важность этих идей не в том, что Достоевский отверг и высмеял Хрустальный Дворец. Фактически он приводит нас, его далеких потомков, к пониманию, что грань между добром и злом проходит не между коммунизмом и нацизмом, а в сознании каждого из нас. Как писал В. Соловьев,

та всемирная гармония, о которой пророчествовал Достоевский, означает... начало той новой земли, в которой правда живет (О великом инквизиторе, 1992: 70). 
И привлекательность этой гармонии в отсутствии насилия, когда справедливость творится во имя сохранения этой гармонии, когда зло оказывается знаком отступления от этого пути, знаком необходимости задуматься и понять, что и как необходимо сделать, чтобы вернуться на путь гармонии и добра. Цели не подсудны. Все полагают, что творят добро. Только представления об этом добре у всех могут быть различны. Но подсудны средства. К этому и призывал Достоевский, об этом и писались антиутопии.

\section{ЛИтеРАтУРА}

Арендт X. О насилии / пер. с англ. Д. М. Дашевского. - М. : Новое издательство, 2014.

Брэдбери Р. Дзен в искусстве написания книг / пер. с англ. Т. Ю. Покидаевой. - М. : Эксмо, 2020.

Кожев А. Понятие Власти / пер. с фр. А. М. Руткевича. - М. : Праксис, 2006.

Люббе Г. В ногу со временем. Сокращенное пребывание в настоящем / пер. с нем. В.А. Куренного. - М. : НИУ ВШЭ, 2016.

О великом инквизиторе : Достоевский и последующие / под ред. Ю. Сильвестрова. - М. : Молодая гвардия, 1992.

Синявский A. Основы советской цивилизации. - М. : Аграф, 2002.

Хархордин О.В. Основные понятия российской политики. - М. : Новое литературное обозрение, 2011.

Хаустов Д. Невинные инквизиторы. Джордж Оруэлл и политическая антропология. - М. : РИПОЛ классик, 2019.

Шмитm K. Государство и политическая форма / пер. с нем. О. В. Кильдюшова. - М. : ИД ГУ-ВШЭ, 2010.

Burnham J. Managerial Revolution, or What is Happening in the World Now. New York : The John Day Co., 1941.

Fabian Society and Young Fabians / LSE Digital Library. - 2000. - URL: https://di gital.library.lse.ac.uk/collections/fabiansociety/tracts (visited on May 28, 2021).

Goldberg J. Liberal Fascism : The Secret History of the Left from Mussolini to the Politics of Meaning Jonah Goldberg. - New York : Penguin, 2009.

Gross B. M. Friendly Fascism : The New Face of Power in America. - New York : South End Press, 1980.

H. G. Wells vs. George Orwell : Their Debate Whether Science is Humanity's Best Hope Continues Today / The Conversation ; ed. by M. Frankel. - 2017. - URL: ht tps://theconversation.com/h-g-wells-vs-george-orwell-their-debate-whether -science-is-humanitys-best-hope-continues-today-88366 (visited on May 28, 2021). 
Wells, Hitler and the World State : Their Debate Whether Science is Humanity's Best Hope Continues Today / George Orwell's Library ; ed. by G. Orwell. 1941. - URL: https://theconversation.com/h-g-wells-vs-george-orwell-their -debate-whether-science-is-humanitys-best-hope-continues-today-88366 (visited on May 28, 2021).

Wells H. G. The Open Conspiracy. - London : Victor Gollancz Ltd., 1928.

$Y$ de $M$. Bernard Shaw and Totalitarianism. Longing for Utopia. - London : Palgrave Macmillan, 2013 .

Tul'chinskiy, G. L. 2021. "Dostoyevskiy: antiutopii KHKH veka i preduprezhdeniye o nastoyashchem [Dostoevsky: 2oth Century Dystopias and a Warning About the Present]" [in Russian]. Filosofiya. Zhurnal Vysshey shkoly ekonomiki [Philosophy. Journal of the Higher School of Economics] 5 (3), 56-72.

\section{GRIGORIY TUL'CHINSKIY}

Doctor of LetTers in Philosophy, Professor

National Research University "Higher School of Economics" (St. Petersburg, Russia); ORCID: 0000-0002-5820-7333

\section{DOSTOEVSKY: 20TH CENTURY DYSTOPIAS}

\section{AND A WARning ABout the Present}

Submitted: June 12, 2021. Reviewed: Aug. 22, 2021. Accepted: Aug. 26, 2021. Abstract: The E. Zamyatin, A. Platonov, O. Huxley, D. Orwell, R. Bradbury dystopias arouse increased interest in our time as a warning about the trends in the development of civilization. These dystopias have significant differences, but they are united by key ideas, which can be traced in the works of F. M. Dostoevsky. We are talking about Dostoevsky's criticism of the ideological roots and possible consequences of the implementation of the program of reorganizing society, focused exclusively on transforming the social environment of life. In this regard, the parable of the Grand Inquisitor in the novel The Brothers Karamazov, which appears as a concentration of the key ideas of the mentioned dystopias, is of particular interest. The main lesson of the paradigmatic dystopia of Dostoevsky's parable is the danger of compulsory good, the desire to realize it "from above", the imperious will of transforming material conditions for universal security and satiety. This logic captures the painful nerve of modern rationalism in its striving to transform the world. Historical experience confirms Dostoevsky's warning that the implementation of such a program requires permanent violence against nature, society, and man. In this situation, not the goals are subject to moral assessment, but the means that are used to achieve the goals.

Keywords: Dystopias, Happiness, Power, Dostoevsky, Violence, Modernity, Socialism.

DOI: $10.17323 / 2587-8719-2021-3-56-72$.

\section{REFERENCES}

Arendt, H. 2014. O nasilii [On Violence] [in Russian]. Trans. from the English by D.M. Dashevskiy. Moskva [Moscow]: Novoye izdatel'stvo. 
Bradbury, R. 2020. Dzen v iskusstve napisaniya knig [Zen in the Art of Writing] [in Russian]. Trans. from the English by T. Yu. Pokidayeva. Moskva [Moscow]: Eksmo.

Burnham, J. 1941. Managerial Revolution, or What is Happening in the World Now. New York: The John Day Co.

"Fabian Society and Young Fabians." 2000. LSE Digital Library. Accessed May 28, 2021. https: //digital.library.lse.ac.uk/collections/fabiansociety/tracts.

Frankel, M., ed. 2017. "H. G. Wells vs. George Orwell: Their Debate Whether Science is Humanity's Best Hope Continues Today." The Conversation. Accessed May 28, 2021. https:// theconversation.com/h-g-wells-vs-george-orwell-their-debate-whether-science-is-hum anitys-best-hope-continues-today- 88366 .

Goldberg, J. 2009. Liberal Fascism: The Secret History of the Left from Mussolini to the Politics of Meaning Jonah Goldberg. New York: Penguin.

Gross, B. M. 1980. Friendly Fascism: The New Face of Power in America. New York: South End Press.

Kharkhordin, O.V. 2011. Osnovnyye ponyatiya rossiyskoy politiki [Key Concepts of the Russian Politics] [in Russian]. Moskva [Moscow]: Novoye literaturnoye obozreniye.

Khaustov, D. 2019. Nevinnyye inkvizitory. Dzhordzh Oruell i politicheskaya antropologiya [Innocent Inquisitors. George Orwell and Political Anthropology] [in Russian]. Moskva [Moscow]: RIPOL klassik.

Kojéve, A. 2006. Ponyatiye Vlasti [The Concept of Power] [in Russian]. Trans. from the French by A. M. Rutkevich. Moskva [Moscow]: Praksis.

Lübbe, H. 2016. V nogu so vremenem. Sokrashchennoye prebyvaniye v nastoyashchem [Im Zug der Zeit] [in Russian]. Trans. from the German by V. A. Kurennoy. Moskva [Moscow]: NIU VSh.E.

Orwell, G., ed. 1941. "Wells, Hitler and the World State: Their Debate Whether Science is Humanity's Best Hope Continues Today." George Orwell's Library. Accessed May 28, 2021. ht tps://theconversation. com/h-g-wells-vs-george-orwell-their-debate-whether-science-i s-humanitys-best-hope-continues-today-88366.

Schmitt, C. 2010. Gosudarstvo i politicheskaya forma [State and Political Form] [in Russian]. Trans. from the German by O. V. Kil'dyushov. Moskva [Moscow]: ID GU-VSh.E.

Sil'vestrov, Yu., ed. 1992. O velikom inkvizitore [On the Grand Inquisitor]: Dostoyevskiy $i$ posleduyushchiye [Dostoevsky and the Subsequent] [in Russian]. Moskva [Moscow]: Molodaya gvardiya.

Sinyavskiy, A. 2002. Osnovy sovet.skoy tsivilizatsii [Fundamentals of Soviet Civilization] [in Russian]. Moskva [Moscow]: Agraf.

Wells, H. G. 1928. The Open Conspiracy. London: Victor Gollancz Ltd.

Yde, M. 2013. Bernard Shaw and Totalitarianism. Longing for Utopia. London: Palgrave Macmillan. 